\title{
生体医療用マイクロ及びナノファイバー
}

\author{
Micro-and Nano-Fibers in Biomedical Application
}

H. プランク

\section{ITV の役割}

我々の所属する研究所は、非常に大きく、バーテンヴェ ルテンベルグ州の経済省の主導のもとの公益組織で、1921 年に創立され、ドイツ最古で最大である。繊維技術、繊維 機械の基礎と応用研究が行われており、ドイツだけではな く日本でも有名である。

このテキスタイルの生産ラインに沿って新しい産業用の テキスタイル、防護服、フィルター、バイオニックス等の 研究が行われている。バイオニックスというのは、自然を 見て、自然界の現象をテキスタイルに人工的に再現しよう という取り組みである。また、ナノ材料の研究も行われて いる。さらに、ライフサイエンス分野として、環境技術、 排水処理などの研究も行われており、アジア、中国、イン ドネシア、南アメリカなどでも活動している。テキスタイ ルの廃棄物というのは、環境にとって大きな問題であるこ とから、何ができるかという研究が行われている。さらに 各種のテキスタイルも研究している。例えば、バイオ材料 ということで、人工藏器などの材料やスマートテキスタイ ルということで、電子デバイスをこのテキスタイルに織り 込むことも研究している。

産業界の要求をもとに研究が行われており、各種製品の プロセス研究をそれぞれ要求に対応して行っている。特殊 なポリマーの開発や、プラスチックの改質など、原材料の 改質を行っており、最適なものができると、産業界に移転 していくという流れになっている。この研究所の研究分野 は、ファイバー・ヤーン技術、表面構造技術、機能化技術、 近代的な生産管理などに分けられており、その他のテーマ も扱われている。このうちのファイバー・ヤーン技術に関 しては、原材料として、綿などの天然の材料からステープ ルファイバーに至るまで研究が行われており、これに関す る機械も作製している。さらに、ポリマーの合成も行われ

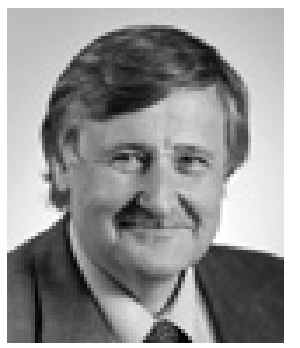

HEINRICH M.F. PLANCK

ドイッ・シュトゥットガルト大学教授 (繊維機械工学), Ph.D.

ITV デンケンドルフ繊維技術研究所所長 URL： www.itv-denkendorf.de/welcome. htm

〈専門〉医用工学、テクニカルテキスタ イル
ていて、主に医療用を目的としている。それらを紡糸して フィラメントを作ることも行っている。また、フィラメン トの機能化、即ち、ねじったり、テキスタイルにしたり、 コーティング等を行っている。

ヤーンのサイジング化、即ち、織物に使うための処理技 術も行っている。

\section{2. ナノ及びマイクロの定義}

ところで、ここでナノとマイクロの定義をしておきたい。 つまり、何がナノで、何がマイクロなのかということは、 実ははっきりしていないので、国際的に同意できる定義を 定めるべきである。ナノの研究をしているといいながら、 マイクロのレベルでやっているということが、往々にして あり、ナノとマイクロの区別を明確にする必要がある。ま ず図 1 にナノ及びマイクロの定義を行う。濾過に関しては、 エアゾール、微粒子、微生物、自動車の排気ガスなどに関 して、マイクロとナノを組み合わせて行われている。テキ スタイルでは、ロータス効果(蓮の葉の超撥水性)に関して は、マイクロファイバーとナノファイバーで行われている。 アルカンタラ (合成皮革) もマイクロ、ナノ構造で作られて いる。いろいろな応用例があり、図 1 の左下は、不織布の フィルターと電界紡糸の不織布と組み合わせたもの、右下 はロータス効果を示している。

図 2 に示すように、この研究所においては、マイクロ及 びナノファイバーで不織布を作る技術を有している。まず 標準的なフィラメントとして $20 \mu \mathrm{m}$ の径のものを作ること

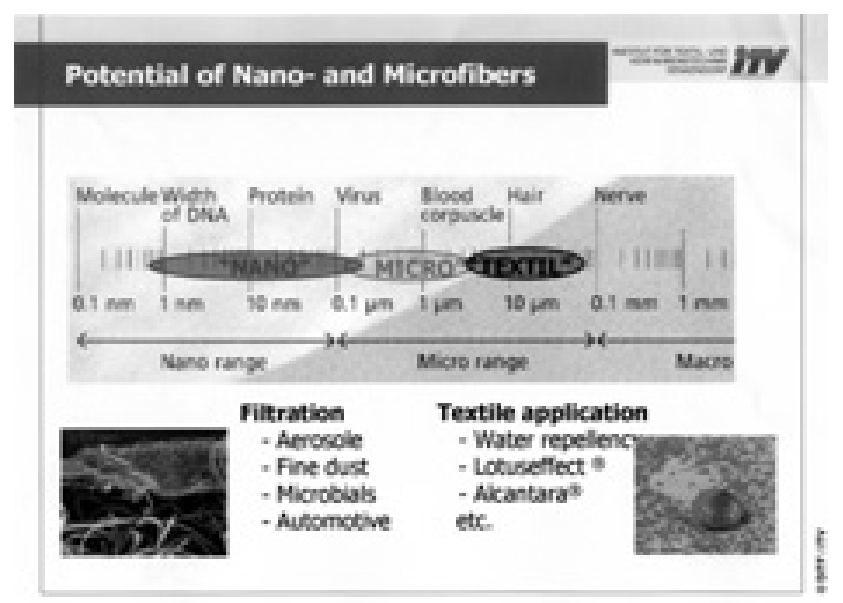

図 1 ナノ及びマイクロの定義 
ができる。マイクロファイバーは $5 \mu \mathrm{m}$ 以上の径である。 メルトブロープロセスも行われて抽り、これによって $1 \mu \mathrm{m}$ ぐらいが可能である。乾式紡糸も行っており、0.5 $\mu \mathrm{m}$ の径 を有する糸の紡糸が可能である。

$100 \mathrm{~nm}$ 以下の直径を有する繊維がナノファイバーで、2 成分高分子による海島構造を利用したナノファイバーの研 究が行われている。また、フラッシュ紡糸では $100 \mathrm{~nm}$ ま で可能であり、電界紡糸では $10 \mathrm{~nm}$ まで可能である。

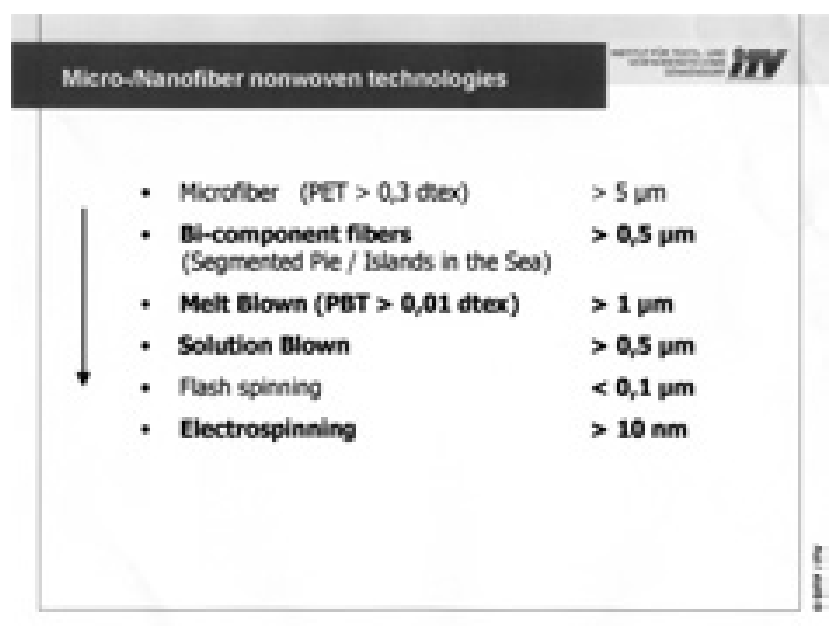

図 2 ITVに打けるマイクロナノファイバー不織布技術

図 3 に示すように本研究所では、織物、編物の技術、不 織布の技術、また、組紐、巻取りの技術も行っている。ま た、こういうものを組み合わせて、ファイバー補強材料も 作れ、引き抜き技術も有している。例えば、衣料用のステ ントを作るための組紐技術、立体的な編み機によって作る 3 次元編物技術、メルトブローによる押し出し成型技術等 を有している。こういうメルトブローの技術によって、将 来的にはナノオーダーのものができる。

\section{3. ロータス効果の応用}

本研究所では、図 4 に示すように、コーティング、ラミ ネート、凝縮、プラズマ処理等の機能化技術を有している。 図 4 の左側は、大気圧下でのプラズマ処理装置で、表面特

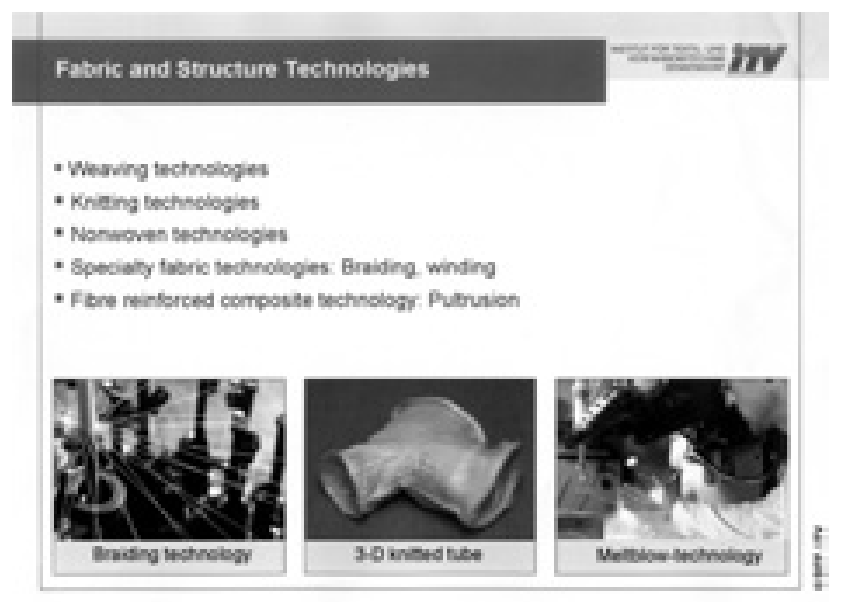

図３ＩTVに拈けるファブリック及び立体構造形成技術
性を変えることができる。これを利用して、ロータス効果 を生み出すためのナノテクノロジーを行っている。バイオ ニックスということで自然界が過去 200 万年の間に生み出 したものを見て、技術的に応用できないかということを研 究している。

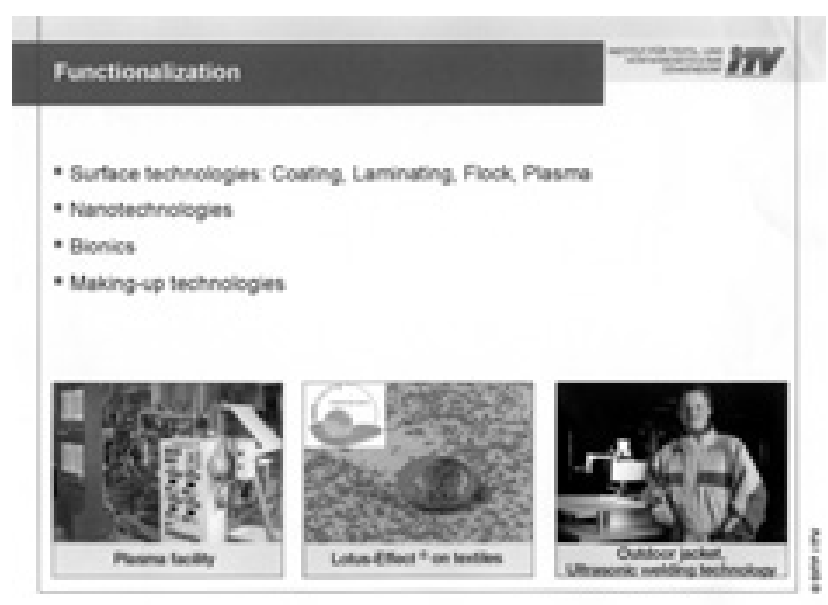

図 4 ITV における機能化技術

困 4 の真ん中がロータス効果を示しており、150 から 160 度の接触角で、水が流れて、表面の埃などが除去される。 非常に効果があるが、力学的な安定性はまだ満足できるも のではない。表面を傷つければ、その性質が変ってしまう。 図 5 に示すように同じシステムであるが、空気を保持す るような表面というものも開発している。つまり、空気を 中に持っていて、このテキスタイルを水の中に入れると、 空気が固定化されてぬれない。これは、水中のアプリケー ションに使えると考えている。つまり、水の中で使えるも のとか、医療用のテキスタイルとして使用できると考えて いる。罒 5 に示すように、バイオニックスという意味では、 クモが水の中に入ってから出てきても、濡れていないとい う性質があるが、非常に小さなナノファイバーが足に生え ているからである。

図 6 に 3 つ構造を組み合わせた自己洗浄テキスタイル の例を示す。織ったファブリックは、大体 $500 \mu \mathrm{m}$ 程度の 次元で、ファイバー単位で見ると $20 \mu \mathrm{m}$ 程度である。さら

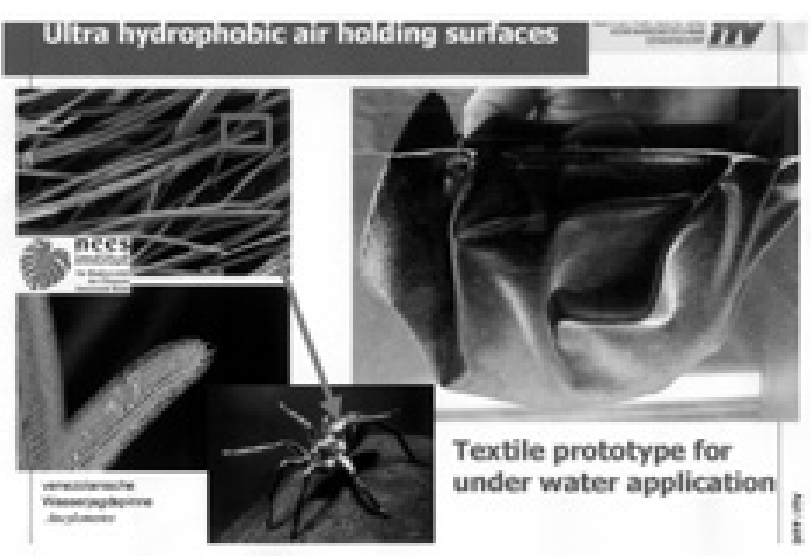

図 5 超疎水性空気保持表面 
にファイバーにナノコーティングを行う。そのスケールは $0.05 \mu \mathrm{m}(50 \mathrm{~nm})$ 程度の大きさになっている。この $3 つ の$ 違ったスケールで組み合わせたことによって、ロータス効 果が得られる。クリーニングを行うと、普通のフロロカー ボン仕上げを行った場合は、污れが付いているが、ナノで わざわざざらつかせた表面の場合は、污れは残っていない。

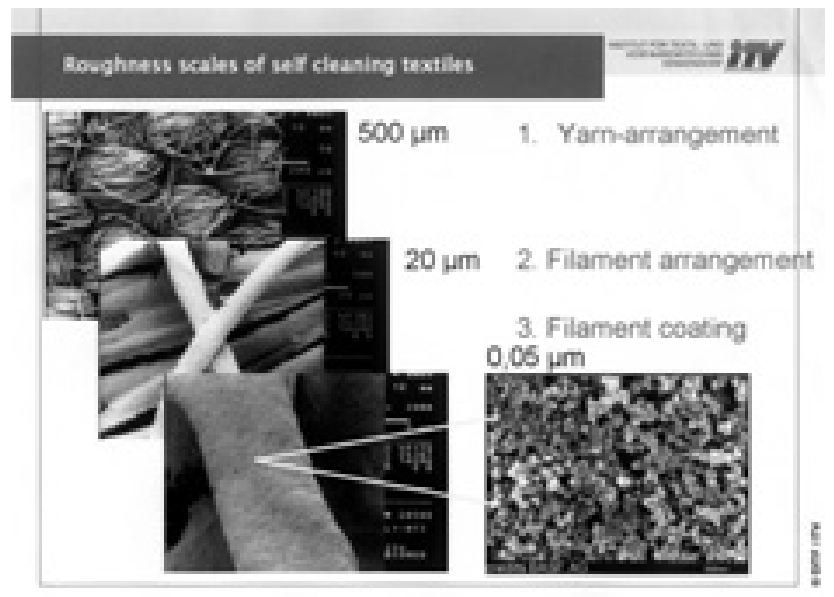

図 6 自己洗浄テキスタイルにおけるスケール目安

\section{4. インテリジェント製品への応用}

図 7 にその他のイノベーティブでインテリジェントな製 品への応用を示す。

スチールのプレートを 2 枚組み合わせ、その間にテキス タイルが入ると非常に軽量で、また絶縁性もあることから、 携帯電話等のさまざまな携帯電子機器に使用できる。繊維 というのは、表面活性があるのでバクテリアをそこで育成 されるということができることから、排水の処理に使うこ とができる。さらに、医療の世界、例えば、手術室で使う ような素材というものがあり、この分野は非常に重要な分 野と考えられる。また、バイオメディカルエンジニアリン グとか、スマートテキスタイルが挙げられる。

スマートテキスタイルは、手術室で使うものとして、で きるだけ長く使用できるものでなければならない。ある程 度使うとそれを洗って、滅菌しなおすという作業が必要に

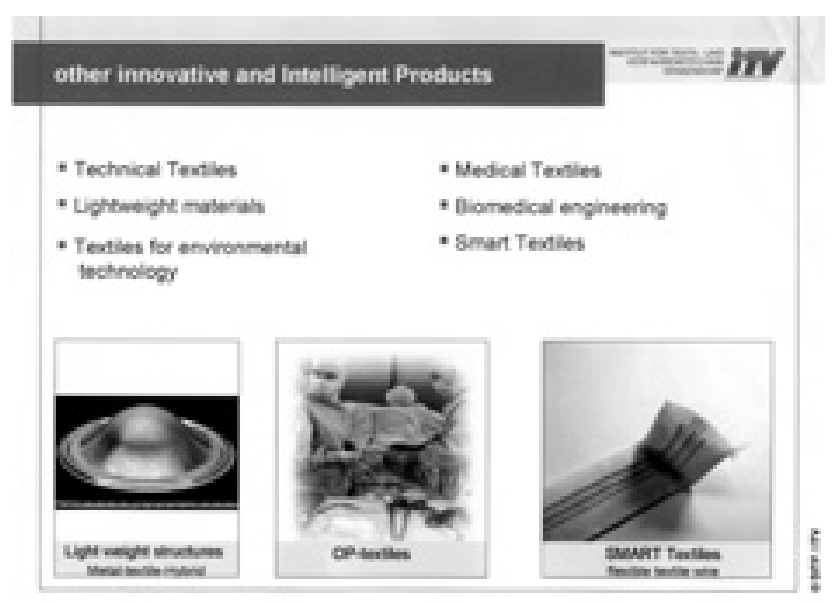

図 7 イノベーティブでインテリジェントな製品への応用
なるので、そのうちにコーティングが取れて、患者や医師 を守るという保護作用がなくなってしまう。そこで、寿命 を長くするという研究が続けられており、100回以上の使 用を目指している。また、ここにナノファイバーを使うと どうなるかということで研究されており、バクテリアが透 過できない膜が作れるのではないかと考えられている。

このスマートテキスタイルは、モニタリングに使用でき る。例えば、赤ちゃんが着ているべストの中にセンサーが 入っている。ナノ粒子を使ったもので、赤ちゃんの生体反 応の心拍数、呼吸、体温、水分などを測定して、それがコ ンピュータに繋がっていて、一定の限界值の中にあるかを モニタリングすることができる。何か問題があった場合は、 アラームが鳴る。データは記録されているため、解析可能 で、医師が見ると詳しい経過がわかる。これは、高齢者に も使用できるし、いろいろな病気の患者に使用可能である。 なお、このテキスタイルは洗えるようになっている。とい うのは、センサーがテキスタイル自体に入っているので、 洗う前に外したり、後から再度付けるという作業が不要に なる。センサーを付けたフレキシブルな太陽電池も作られ ている。これをテキスタイルの中に入れても、テキスタイ ルとしての挙動には変化はない。例えば、発光ダイオード 入りの膜は、夜は発光するので、車からも見え安全である。 次にこのテキスタイルを体の中に埋め込むために、いろ いろな方面への応用が考えられている。心蔵をサポートす るための人工血管、心臓の弁、やけどをした時の人工皮膚、 また、骨の結合が考えられている。

人工血管、ヘルニアのネット、再吸収性のステントなど を作っている。図 8 に示すように再生医療工学の観点から、 バイオハイブリッドの組織を作るということも研究してい る。患者に新しい臓器が必要になった場合、その患者さん 本人の細胞も使うこともでき、また、その他の動物のもの を使うということも考えている。日本ではできないと思わ れるが、ドイッでは他の人、動物からの細胞を使うことが できる。細胞を洗浄して、テキスタイルの構造体と組み合 わせて、培養を行い、それをもう一度患者に移植する。つ まり、体外で一度培養したものを入れることになる。

細胞もそうであるが、テキスタイルというのは基本的に は単なる単体であるから、体の中に残る性質を利用したり、 あるいは溶けて消失する性質を利用することができる。

軟骨の再生に関しては、ファイバーの構造を細胞が認識 し、ファイバーの径にしたがって成長する。例えば、軟骨 細胞がファイバーの上を歩いていくことになり、ある種の 結合体、凝集体のようなものを作って、新しい軟骨を形成 する。

バイオメカニックスといったものを使用して、この糸を 改良すれば、軟骨や耳とか鼻ではなく、関節の軟骨も作れ るのではないかと考えている。また、バイオハイブリッド の肝臓に関しては、豚の肝細胞を使うことが可能であり、 また、大人から取った肝細胞を使うことも可能で、非常に うまく行っている。生成を行って、それをテキスタイルの 


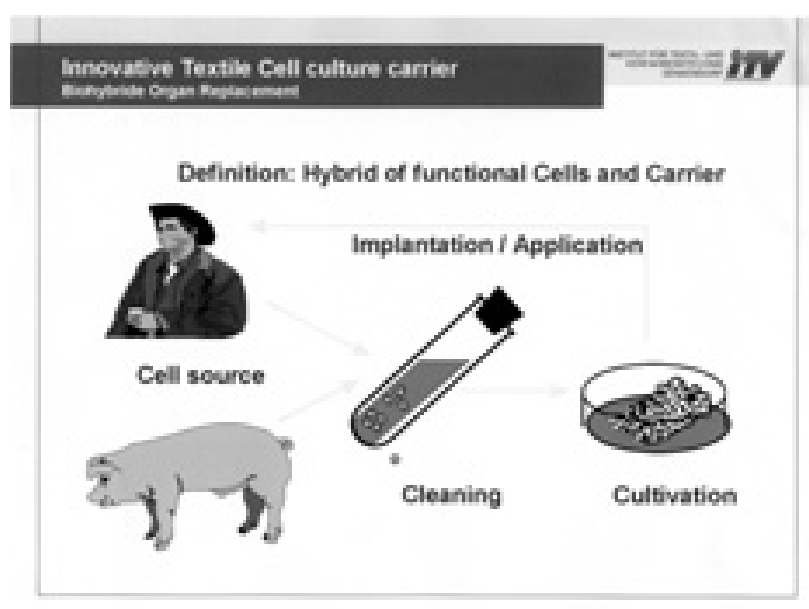

図８テキスタイルを用いたバイオハイブリッド

システムに植えつけると、その糸の中で、テキスタイルが 細胞キャリヤーとなる。そのシステムが体外のシステムと して、患者の体内に導入される。

図 9 は人工肝蔵で、血液がポンプで体外循環している。 肝細胞は、血清をきれいにするという役割があり、患者 から来た血液中の血漿を分離させる役割を有している。バ イオリアクターにきて、酸素が与えられる。血液浄化した ものが患者の体内に戻り、肝臓をサポートするシステムに なっている。例えば、患者が肝不全であったりしたような 場合、その人の血液を浄化することによって、肝蔵の機能 が回復することがあり、また、肝移植をするまでのサポー トのために使うこともできる。

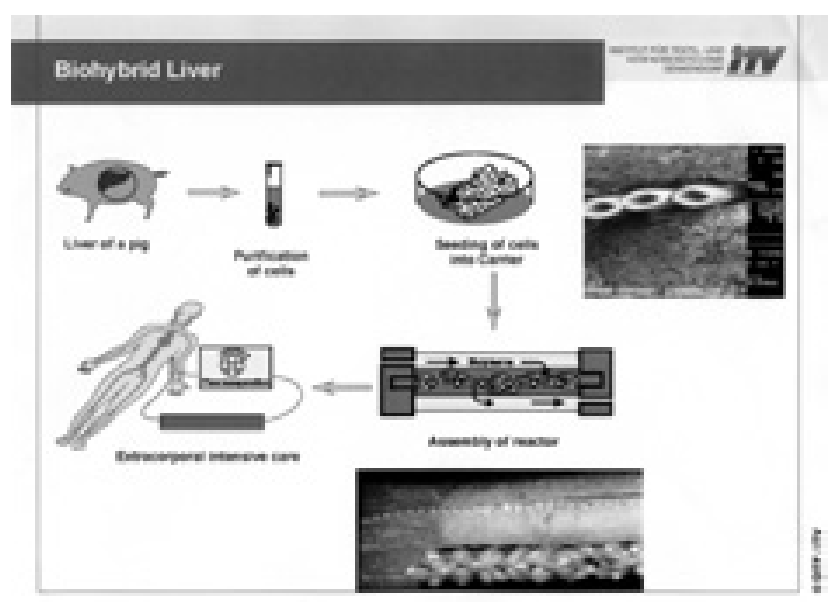

図 9 人工肝臓

困 10 に人膵臓を示す。膵臓についても、マイクロあ るいはナノのファイバーを使用してシステムを実現できる。 インシュリンは䐺臓の中のランゲンハンス島でつくられる が、血管の中に毛細管膜があり、その中にこのインシュリ ンを作るものを入れる。そのとき、外から入れた細胞を拒 絶しないようにする。即ち、ケプラーの膜で対外由来の細 胞が守られるようになっている。この細胞がインシュリン を作ったり、止めたりするようになる。

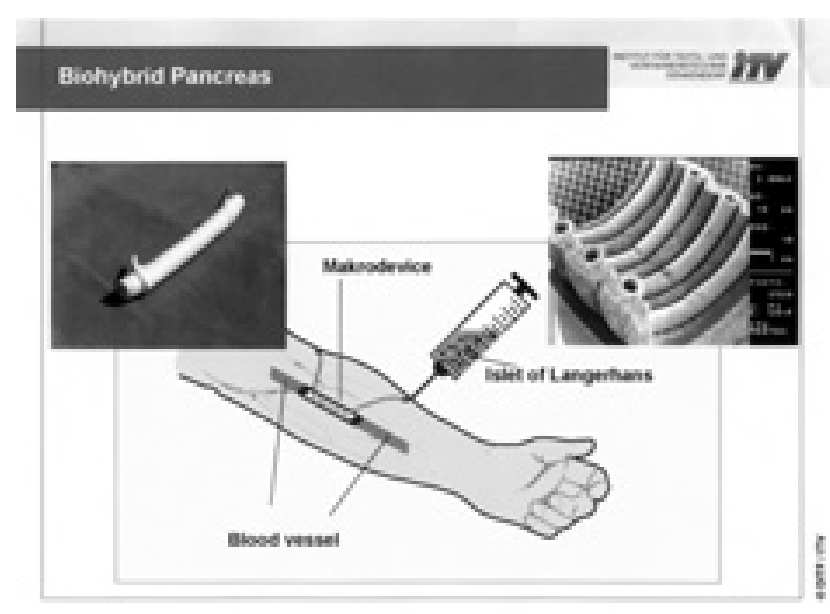

図10 人工㬸臓

この細胞は、今のところ 150 日生き続け、一定の期間が たった後、古い細胞を取り出して、新しいものと交換する が、それも問題なくできた。

神経の再生も可能である。例えば、神経が切断された場 合、つなぐ必要があるが、それはなかなか難しい。そこで、 体の中に再吸収されるような素材で細い管を作り、切れて しまった神経をこの管を用いて繋ぐと、神経の末端が伸び てきて、再結合する。

\section{5. おわりに}

研究に当たっては、いろいろなネットワークが作られて いる。研究所内はもちろんのこと、ドイツ国内や州の間で も作られている。また、大学間のセンターでもジョイント ベンチャーとして、2つ以上の大学と一緒になって、活動 が行われている。産業界ともバイオミメティックス、バイ オニックス、燃料電池といった分野で共同研究が行われて いる。さらに、ヨーロッパには「テキストラネット」とい う組織があり、この一員にもなっている。

この半年、信州大学の方々がこの研究所に来て、プロジェ クトをどのように進めるか、大学間や産業界とどういう連 携をするか、という話をしている。ITV 研究所は、9 部門 で活動がいっており、それぞれの部門の責任者がどのよう なことを実施していくかを決めている。またそれぞれの部 門は密接に連携している。さらに、産業界との連携を密に して、開発されたノウハウが産業界で利用してもらえるよ うに技術移転も積極的に行っている。

なお、ドイッでは、連邦政府、州からの補助があり、ま た、基礎研究を推進するための DFG(ドイツ学術振興会) からも補助が出ている。本研究所の全予算の約 $45 \%$ は産 業界からのものである。

テキスタイルの研究はもう限界にきているという意見も あるが、そうではなく、まだまだ十分研究の余地があり、 特に、ナノの世界に扎いては、今後大きな期待ができる。

(文責 谷岡明彦) 